DOI: https://doi.org/10.47405/aswj.v5i4.152

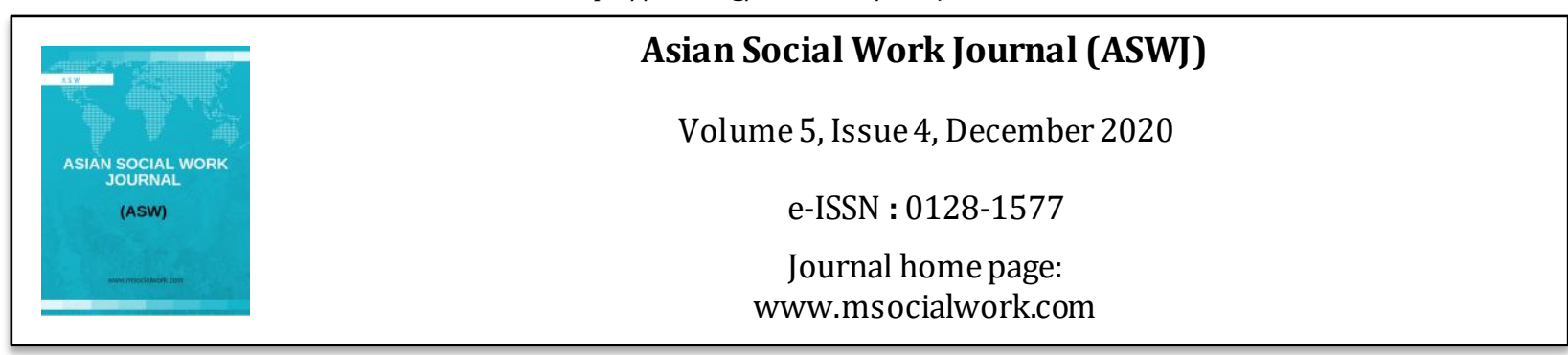

\title{
Local Government Efforts in Promoting the Development of Tourism Area of Pari Island, DKI Jakarta
}

\author{
Andrey Banyudoyo ${ }^{1}$, Triyanti Anugrahini1 ${ }^{1}$ \\ ${ }^{1}$ Department of Social Welfare Science, Faculty of Social and Political Sciences, University of Indonesia, Indonesia
}

Correspondence: Andrey Banyudoyo (banyudoyo.andrey@yahoo.de)

\begin{abstract}
As one of the countries that has rich natural potential, Indonesia is an archipelago country that has extraordinary natural potential. Therefore, to ensure maximum efforts from the implementation of these efforts, a regulation was formed whereby the Central Government authorizes the Regional Government to maximize its potential. the. . The development of national tourism which is quite good in the last five years provides opportunities for each region that has the potential to further develop and maximize all the potential of its region. This then provides an opportunity for the government to build concrete steps in developing an area that originally had potential in the end. can be used to encourage the area to become a tourist area, where these conditions have an impact on the community in the area. The purpose of writing this article is to find out the efforts of the local government in building community welfare through the development of tourist areas on Pari Island. The method used in this writing is a qualitative descriptive type. Data collection techniques in the form of documentation study, observation and in-depth interviews. By taking informants using purposive sampling. The results obtained are that the government has made various efforts to develop the tourism area on Pari Island.
\end{abstract}

Keywords: international non-government organizations, child protection, international programs and institutions

\section{Introduction}

Indonesia is an archipelago located in Southeast Asia. Indonesia is also a constitutional state, and as a rule of law, every Indonesian citizen has a common ideological platform, namely Pancasila. The fifth precept in Pancasila reads "social justice for all Indonesian people". The fifth precept states that every Indonesian citizen has the right to equal justice, both in the economic, social and legal fields. As a very large archipelagic country, of course the Indonesian government has several very diverse problems. This problem is caused by a very large area, there are various kinds of cultures, which have different approaches. Because the area is very large, the government then cannot control everything from the center, and therefore it needs local governments that are assigned to regulate an area that is desired to be changed for the better. The condition of Indonesian tourism in 5 five years has experienced significant growth, even in 2018 Indonesian tourism grew $12.58 \%$ or reached 15.81 million foreign tourists (Syambudi, 2019). In addition, according to the Ministry of Tourism, foreign exchange earnings from the tourism sector in 2018 reached 17 billion dollars and this year, assuming the number of tourists reaches 20 million, the country's foreign exchange income from the tourism sector is projected to reach 20 billion dollars, this means that the tourism sector will become a revenue sector. the largest countries beat the oil and gas, coal, and palm oil sectors (Nasional.kontan.co.id, 2019). 
DOI: https://doi.org/10.47405/aswj.v5i4.152

The tourism sector is one of the most important sectors in Indonesia, this is because this sector provides the largest foreign exchange contribution to this country. Tourism in Indonesia has experienced a very significant increase from year to year, according to data in the Central Statistics Agency, in the last eight months of 2019, there was an increase in foreign tourist visits to Indonesia, from a total of 707,700 arrivals who entered through the air gates at January 2019, there was an increase of 2,84230 arrivals in August, which if added up to 992,020 tourists in it (Central Bureau of Statisctic, 2019; Widowati, 2019). The increase that has occurred in the tourism sector is certainly due to an increase in the quality of tourism targeted in Indonesia. If reanalyzed, these improvements are certainly not only supported by the central government, but also by the governments of each region. This increase is of course not finished, because there are various kinds of things that can cause this increase to continue to increase or a decrease in it. This then becomes the task of the government to keep this number stable by issuing various kinds of policies that benefit various parties, both from migrants, local parties, and the private sector. This condition occurs when tourism facilities in the area are managed by the private sector.

The development of natural tourism carried out by the government is based on the results of research conducted by Simamora and Sinaga (2016), Kanuna (2014), Syahfutra (2014), Arifin (2017), and Khasanah (2015). Based on the results of research conducted by previous researchers, the implementation of tourism development, especially natural tourism, was carried out by the government by conducting multi-approaches involving several parties to be able to support this development. Several studies mention the role of the government in efforts to develop marine tourism, this can be obtained from several studies such as Salin and Purbani (2015), Afandi and Hakim (2017), Yani, Setiawan, and Kurnianingsih (2019), Kagungan and Yulianti (2019), Palupi, Ira and Risfandi (2019). In this study, the same as research conducted on the thematic development of natural tourism, which is carried out by the government as a whole is by developing existing facilities and involving several parties who are aligned and concerned with marine tourism assets and synergize to be able to support the tasks carried out by the government. and some of these parties to develop tourism in each area that is the location of the research.

The role played by the government in tourism development efforts in general is in accordance with the results of research conducted by Anggraeni and Fadlurrahman (2018), Medi (2017), Martins, Paturusi, and Surya (2017), Kubickova (2016), Idris, Ati and Abidin (2019). Still the same as the results of research on the natural tourism and marine tourism sections in the tourism section in general, this also occurs in the role of the government to develop tourism in general by focusing on multi-perspectives by synergizing the implementation of development both by the government and the private sector. Based on the results of previous studies, the question of this research is how the efforts made by the local government in initiating the development of tourist areas in Pari Island, Thousand Islands?

\section{Methodology}

The research approach used in this research is qualitative. This is as the purpose of this study is to determine the role of the government in tourism development in Pari Island, Thousand Islands, DKI Jakarta. Therefore the choice of this approach is also based on the thinking of Neuman (2014) that qualitative research involves the language of cases and contexts using bricolage which means improvisation of the creativity by the researchers, examining social processes and cases in social contexts and research interpretation. or meaning in a certain socio-cultural order (Neuman, 2014). In an effort to support the objectives of this research, research design used in this research is descriptive research. According to Neuman (2014) descriptive research aims to provide an overview by using words and numbers and presenting profiles (problems), classification of types or an outline of the stages of the research. Related to this, this type of descriptive research is able to describe the situation, social arrangement and the relationship of the objectives of this study. The selection of key informants in this study was carried out by considering the characteristics of the informants by using purposive sampling technique. The purposive sampling technique was chosen because this technique has the basic principle of selecting cases and individuals in qualitative research conducted that places 
DOI: https://doi.org/10.47405/aswj.v5i4.152

investigative research questions at the forefront and requires a level of consideration at which sampling needs to be carried out (Bryman, 2012).

\section{Result and Discussion}

Based on the results of field findings carried out by researchers through data collection techniques and also predetermined data collection schedules, the information carried out by the local government in developing tourist areas on Pari Island such as:

\section{Provision of Information}

To make an effort to initiate the development of a tourist area on Pari Island, it was initially carried out by providing information to the public regarding the potential that the community has. Information is Data that has been put in a meaningful and useful context is communicated to recipients for use in decision making (Suyanto, 2000). This method is expected to increase people's understanding of their potential so that people have the desire to be able to develop their potential independently. This ef fort is certainly in line with the information provided by the local government through several local community meetings which of course also use community leaders around Pari Island. This is certainly relevant to the concept of behavior which consists of cognitive where through good cognitive it is expected that the community will have the appropriate cognitive, this is of course expected to cause the behavior displayed by the community as expected in relation to efforts to develop tourist areas in Pari Island.

\section{Multisectoral approach}

One of the next steps undertaken by the local government as part of the initiative to develop Pari Island is to undertake a multisectoral approach. Cross-sector collaboration is needed to develop an intervention model (Aimanah, Budisuari, \& Machfutra, 2018). The purpose of the multisectoral approach is that the government initiated the development of tourism areas in Pari Island by using various approaches such as economic, social, cultural, and of course political. The multisectoral approach is carried out with the aim of the cold main message conveyed by the government which can be clearly accepted by various aspects of society thus expanding the impact in mobilizing the community to support efforts to develop tourist areas on Pari Island.

\section{Infrastructure development}

To be able to ensure that the community is the main organizer of efforts to develop tourist areas on Pari Island, of course the government needs to build trust in the community for the seriousness of the government regarding the development of tourism villages on Pari Island. Adequate infrastructure to support economic activity (Warsilan \& Noor, 2015). Therefore, to make it happen, one of the ways is by providing physical evidence to the community, so that people believe and have seriousness in participating in developing Pari Island as a tourist area. Several examples have been taken by the government, such as building infrastructure relevant to tourism development such as ports, places of worship, lodging, and other supporting facilities such as trash cans.

\section{Conclusion}

In general, based on the field findings received by the researchers, information was obtained that there were several efforts made by the local government to be able to initiate the development of tourist areas in Pari Island, such as providing information, a multisectoral approach and of course infrastructure development. Through these stages or efforts, the local government hopes that there will be an increase in the enthusiasm of the community to participate in organizing tourism development efforts on Pari Island. In addition, to be able to increase tourism development on Pari Island, it is hoped that the local government will collaborate with other non-governmental parties so that the 
DOI: https://doi.org/10.47405/aswj.v5i4.152

community has enthusiasm who continuously wants to be able to participate in the development of the

Pari Island tourist area.

\section{Acknowledgment}

This research would not have been possible without the support of several parties, therefore through this opportunity the researcher would like to thank several parties such as all employees of the Department of Social Welfare Sciences, Faculty of Social and Political Sciences, University of Indonesia and of course all informants who wish to be a source of information in this study.

\section{References}

Anggraeni, Dewi Fitria \& M.P.A. Fadlurahman. (2018). Peran Dinas Kebudayaan Dan Pariwisata Kabupaten Temanggung Dalam Pengembangan Objek Wisata. Jurnal Mahasiswa Administrasi Negara (JMAN), 2(1).

Aimanah, Ira Ummu, Budisuari, Made Asri, \& Machfutra, Eka Denis. (2018). Model Pendekatan Multisektor untuk Peningkatan Status Gizi Ibu dan Anak Etnis Molo di Kabupaten Timor Tengah Selatan. https: //ejournal2 .litbang. kemkes. go.id/ index.php /bpk/ article/ view/85 1554. Retrived from December 2019.

Arifin Ahmad Zainul. (2017). Peran Pemerintah Daerah Dalam Pengembangan Kawasan Desa Wisata Pada Kampung Bintan Bekapur Desa Bintan Buyu Kecamatan Teluk Bintan Kabupaten Bintan. Retrived from December 2019.

Bryman, A. (2012). Social Research Method, $4^{\text {th }}$ ed. United States: Oxford University Press Inc.

Idris, T M., Ati, N. U. \& Abidin, A.Z (2019). Peran Pemerintah Dalam Pengembangan Wisata Kampung Jodipan Dan Kampung Tridi (Studi Kasus Di Kelurahan Jodipan Dan Kelurahan Kesatrian Kecamatan Blimbing Kota Malang). http://riset.unisma. ac.id/index.php/rpp/article/view/3587. Retrived from December 2019.

Kagungan, D., \& Yulianti, D. (2019). Sinergi Di Antara Pemangku Kepentingan Untuk Mengembangkan Pisang Pulau Sebagai Pariwisata Laut: Kasus Wilayah Yang Tidak Dikembangkan. https://e-journal.unair.ac.id/MKP/article/view/8265. Retrived from December 2019.

Kanuna, R. S. (2014). Peranan Pemerintah Daerah Dalam Pengelolaan Potensi Pariwisata Di Kabupaten Toraja Utara. http://repository.unhas.ac.id/bitstream/handle/123456789/9875/SKRIPSI\%20RESKY\%20SIRU PANG\%20KANUNA\%2C\%20NIM\%20E12108532.pdf?sequence=2. Retrived from December 2019.

Khasanah, Z. (2015). Peran Dinas Pariwisata Kulon Progo dalam Pengembangan Potensi Wisata Goa Kiskendo (Studi di Desa Jatimulyo, Kecamatan Girimulyo, Kabupaten Kulon Progo). http://digilib.uin-suka.ac.id/19393/2/11230084_BAB-I_IV-atau-V_DAFTAR-PUSTAKA.pdf. Retrived from December 2019.

Kubickova, M. (2016). The Role of Government in Tourism: Linking Competitiveness, Freedom, and Developing Economies.

Kubickova, M. (2016). the role of Government in tourism: linking competitiveness, freedom, and Developing economies. Czech Journal of Tourism, 5(2), 73-92. DOi: 10.1515/cjot-2016-00005. Retrived from December 2019.

Martins, Z, Paturusi, S.A \& Surya, I.B.K. (2017). Peran Pemerintah Dalam Pengembangan Potensi Pariwisata Di Area Branca Metiaut, Dili. JUMPA, 3(2).

Medi, R. (2017). Peran Pemerintah Daerah Dalam Pengelolaan Potensi Pariwisata Buntu Burake Di Kabupaten Tana Toraja. Jurusan Ilmu Administrasi Negara, Fakultas Ilmu Sosial, Universitas Negeri Makassar http://eprints.unm.ac.id/11136/1/JURNALTIN.pdf . Retrived from December 2019.

Nasional.kontan.co.id. (2019). Sepanjang 2019, Devisa Sektor Pariwisata Mencapai Rp. 280 Triliun. https://nasional.kontan.co.id/news/sepanjang-2019-devisa-sektor-pariwisata-mencapai-rp-280triliun. Retrived from December 2019. 
DOI: https://doi.org/10.47405/aswj.v5i4.152

Neuman. W. L. (2014). Social Research Methods: Qualitative and Quantitative Approaches. New York: Pearson.

Palupi, R., Ira, D. \& Risfandi. (2019). Strategi Pengembangan Wisata Bahari Desa Namu Guna Mendukung Perekonomian Masyarakat Sadar Wisata. http://journal.ipb.ac.id/index.php/jurnalmpi/ Vol. 14 No. 1. Retrived from December 2019.

Salin, L. H. \& Purbani, D. (2015). Pengembangan Pariwisata Bahari Berbasis Masyarakat Di Pulau Kaledupa, Kabupaten Wakatobi, Provinsi Sulawesi Tenggara (Community Based Marine Tourism Development In Kaledupa Island, Wakatobi Regency, South East Sulawesi Province). https://jurnal.ugm.ac.id/JML/article/view/18765. Retrived from December 2019.

Simamora, R. K \& Sinaga, R.S. (2016). Peran Pemerintah Daerah dalam Pengembangan Pariwisata Alam dan Budaya di Kabupaten Tapanuli Utara. Jurnal Ilmu Pemerintahan dan Sosial Politik, 4(1), 79-96

Suyanto. (2000). Refleksi dan Reformasi Pendidikan Indonesia Memasuki Millenium III. Yogyakarta: Adi Cita.

Syahfutra, A. (2014). Peran Pemerintah Daerah Dalam Pengembangan Obyek Wisata Istana Sayap Di Kabupaten Pelalawan Tahun 2009 - 2011. Jom FISIP, 1(2).

Tirto.co.id. Syambudi, Irwan. (2019). BPS: Indonesia Dikunjungi 15,81 Juta Turis Sepanjang 2018. https://tirto.id/bps-indonesia-dikunjungi-1581-juta-turis-sepanjang-2018-dfGP. Retrived from December 2019.

Warsilan \& Noor, A. (2015). Peranan Infrastruktur terhadap Pertumbuhan Ekonomi dan Implikasi pada Kebijakan Pembangunan di Kota Samarinda. MIMBAR, 31(2). 